\title{
Exmo Sr. Secretário de Estado da Saúde de São Paulo
}

José da Silva Guedes

Gostaria de, em primeiro lugar, agradecer o convite para participar da abertura deste Encontro. Pretendo não me alongar, apenas colocando algumas reflexões que desejo compartilhar com os participantes.

Lembro-me que quando assumi a Secretaria Municipal de Saúde, uma reunião de Departamentos de Medicina Preventiva realizada em Uberlândia teve um tom festivo na medida em que outros professores da nossa área também estava assumindo postos de governo, responsabilidades político-administrativas.

Hoje, no comando da Secretaria Estadual de Saúde da qual, por falta de condições para trabalhar estive afastado nos últimos períodos, percebo importantes diferenças em relação a situações passadas.

A primeira refere-se ao excelente quadro de administração então existente e que perdeu uma grande quantidade de elementos, que passaram a exercer suas atividades em outras esferas, notadamente aquela municipal.

Uma segunda constatação diz respeito a formação de profissionais necessários à Saúde Pública. Desde que, particularmente, acabaram com o mercado de trabalho para os assim chamados sanitaristas ou profissionais da medicina social, houve um certo alijamento de pessoas que poderiam ter interesse na área mas que não encontram condições favoráveis. Veja-se o que tem acontecido com a demanda para os nossos programas de residência, quase inexistente.

O reflexo desta situação no trabalho da Secretaria é claramente perceptível. Por exemplo, a Secretaria de Saúde hoje encontra-se muito mais recheada de informações, números e dados. Todavia há uma grande pobreza de análise destes dados que não são transformados em indicadores que permitem melhor apreender a real situação de saúde do Estado de São Paulo. Encontramos hoje, na Secretaria, uma enorme quantidade de computadores que, no entanto, não têm conseguido produzir até mesmo pequenos cruzamentos que permitam conclusões necessárias à organização do trabalho. Não vai aqui nenhuma crítica às pessoas que montaram o sistema de informações. Ao contrário, quero home- 
nageá-las pelo trabalho desenvolvido. O que destaco é a necessidade da Secretaria ser dotada de uma capacidade analítica que realmente embase as decisões.

Um outro aspecto que gostaria de comentar, refere-se às tarefas da Secretaria. Englobando todas as atividades do setor saúde, identifico uma distribuição extremamente importante, caracterizada pelo que qualificaria de "desvio assistencialista" ou "função curativista", se quiser. São enormes a preocupação e o trabalho da Secretaria em organizar a assistência médica, principalmente quando se quer uma assistência com qualidade e que leve a bons resultados.

Ainda que no setor saúde estejamos sempre reclamando da escassez de recursos, a quantidade de dinheiro envolvido na assistência médica é muito grande. Por isso, a maior parte do tempo e do trabalho é dedicada a questões do tipo: como é que vamos gastar? Como é que estão gastando? Como é que vamos controlar? Em conseqüência, outras questões de grande importância acabam sendo relegadas a segundo plano.

Analisando as coisas desta forma, estamos propondo, no interior da Secretaria, algumas reformulações que, diga-se de passagem, tem custado pesadas críticas ao grupo que elaborou a proposição. Penso que as críticas vêm de uma análise muito rápida da proposta, até mesmo pelo tipo de interrogação que é feita: será que voltaram os dinossauros?; será que de novo vai se separar o que é curativo do que é preventivo?

A realidade mostra que esta é uma análise muito ligeira da proposta. Quando vemos o envolvimento que nossos diretores regionais tem, com a assistência médica, com sua organização e seu controle, ficamos convencidos de que, se não tiver um time comprometido no seu dia-a-dia, todos os dias, com os aspectos da saúde coletiva, eles certamente serão esquecidos. Vamos continuar gastando todo o nosso tempo e esforço com a chamada assistência, enquanto as atividades da saúde coletiva não encontrarão condições de serem realizadas.

Nestes dois meses de trabalho esta situação tem ficado cada vez mais clara, assim como a necessidade da colaboração dos companheiros da área de saúde coletiva e epidemiologia na condução da secretaria.

Vamos iniciar o que estamos chamando de "retreinamento" das pessoas para um planejamento integral da assistência à saúde. Por aí, pretendemos fazer com que os diretores regionais voltem a ter poder para que juntamente com os municípios, possam planejar a assistência que se quer fazer, de modo ordenado e hierarquizado. Será preciso criar assessorias e consultorias para as diferentes direções regionais e aí, as escolas teriam um papel a desempenhar.

Não estamos pensando em contratar boas escolas ou cursos para treinar estas pessoas. Queremos é contar, nestas escolas, com pessoas experientes que 
possam colaborar estreitamente na elaboração de planejamento regional na sua acepção mais completa, mais integral. Com isso, estaríamos implementando um processo de, vamos dizer, "treinamento em serviço", muito importante para se fazer este planejamento integral.

Prometi não me alongar e gostaria, para terminar, de dizer o seguinte: muito da epidemiologia simples tem se mostrado extremamente importante para a melhor conclusão dos destinos da Secretaria. Muito da epidemiologia complexa que vocês, mais modernos, sabem fazer, também tem uma grande contribuição a dar, por exemplo, na análise da enorme quantidade de dados já acumulados e que precisam ser trabalhados. A Secretaria, sozinha, não vai ter fôlego para realizar estas tarefas. Assim, tenho um desafio a fazer aos companheiros da epidemiologia, esperando ter os recursos necessários para que este desafio não fique no ar, mas que se concretize na vinda de vocês para ajudar no nosso trabalho.

Quero felicitar os organizadores do Encontro e desejar que ele possa, realmente, trazer os melhores frutos, a todos nós. 